Check for updates

Cite this: RSC Adv., 2019, 9, 29909

Received 25th July 2019

Accepted 14th September 2019

DOI: $10.1039 / c 9 r a 05777 c$

rsc.li/rsc-advances

\section{Discovery of diazahexa/hepta cyclic cage-like compounds with broad-spectrum antifungal activity against Candida and Cryptococcus species $\uparrow$}

\author{
Anthony Weinstock, $+^{\mathrm{a}}$ Natarajan Arumugam, $\mathbb{D} \ddagger^{* \mathrm{~b}}$ Abdulrahman I. Almansour, \\ Raju Suresh Kumar iD ${ }^{b}$ and Shankar Thangamani (D) *c
}

\begin{abstract}
Invasive fungal infections caused by Candida and Cryptococcus species lead to life threating infections in immunocompromised individuals. Furthermore, increasing incidence of fungal strains resistant to FDAapproved antifungal drugs along with the paucity of antifungal drugs warrants novel drugs to treat invasive fungal infections. In this study, we investigated the antifungal activity of a novel series of diazahexa/hepta cyclic cage-like compounds. Results indicate that compounds with unsubstituted and o-methyl substitution on aryl rings exhibit potent broad-spectrum antifungal activity against various fungal strains. In addition, these compounds showed significant inhibitory activity against Candida hyphae and biofilm formation. Collectively, results from this study indicate that these compounds are promising candidates to develop as novel antifungal drugs to treat drug-resistant fungal infections.
\end{abstract}

\section{Introduction}

Fungal infections, especially invasive candidiasis, are among the most common blood stream infections in the hospital setting, particularly among cancer patients and patients in intensive care units. ${ }^{1-4}$ Cryptococcus spp. also demonstrates high prevalence in immunocompromised patients infected with human immunodeficiency virus (HIV). ${ }^{5}$ With increased dependence and utilization of broad-spectrum antifungal drugs, there has been a causal increase in resistance to antifungal drugs across Candida and Cryptococcus species. ${ }^{6-8}$ However, with the most recent antifungal drug approved in the 2000s, only a limited number of antifungal drugs are currently available to treat these fungal infections..$^{\mathbf{9 1 0}}$ Coupled with the fungal strains developing resistance to current drugs and paucity of FDAapproved antifungal agents, an unmet and urgent need to develop new antifungal drugs are necessary to treat the systemic invasive fungal infections. ${ }^{\mathbf{1 0 - 1 2}}$

In this study, we aim to identify novel compounds against the important human fungal pathogens, Candida and

${ }^{a}$ Arizona College of Osteopathic Medicine, Midwestern University, 19555 N. 59th Ave., Glendale, AZ 85308, USA

${ }^{b}$ Department of Chemistry, College of Science, King Saud University, P.O. Box 2455, Riyadh 11451, Saudi Arabia. E-mail: antarajan@ksu.edu.sa; Fax: +966 4675992; Tel: +9664675907

${ }^{c}$ Department of Pathology and Population Medicine, College of Veterinary Medicine, Midwestern University, 19555 N. 59th Ave., Glendale, AZ 85308, USA. E-mail: sthang@midwestern.edu; Fax: +1 623537 6399; Tel: +1 6235376378

$\dagger$ Electronic supplementary information (ESI) available. See DOI: 10.1039/c9ra05777c

\$ Co-first authors.
Cryptococcus species. Our results indicate that compounds 5a and $\mathbf{5 g}$ exhibit potent inhibitory activity against fungal strains and have the potential to develop as new antifungal drugs.

\section{Results and discussion}

\section{Chemistry}

Recently, we synthesized a series of diazahexa-/hepta cyclic cage-like compounds (Fig. 1) via domino multicomponent protocol $^{13}$ that involved (i) 1,3-dipolar cycloaddition and (ii) concomitant annulation steps (Scheme 1). 1,3-Dipolar cycloaddition reaction of the azomethine ylide generated in situ from an equimolar amount of acenapthenequinone (1) and Lphenylalanine (2), with a series of bisbenzylidenepiperidin-4ones 3 in methanol under reflux condition afforded the cage-
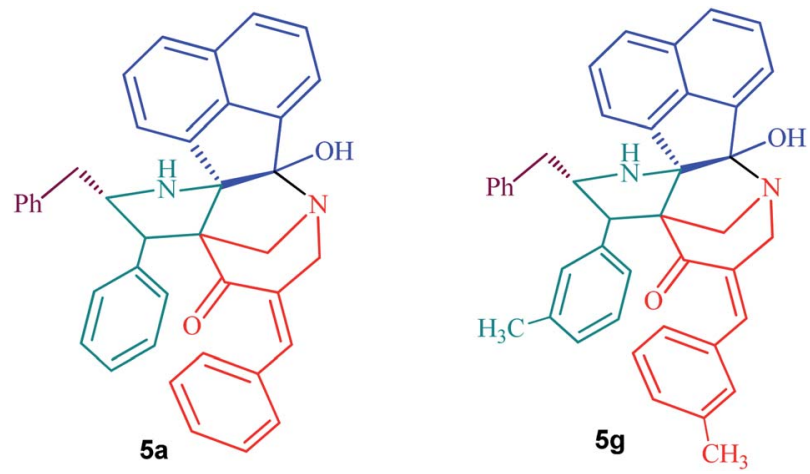

Fig. 1 Structure of potent diazahexacyclic cage compounds $5 a$ and $5 \mathrm{~g}$. 

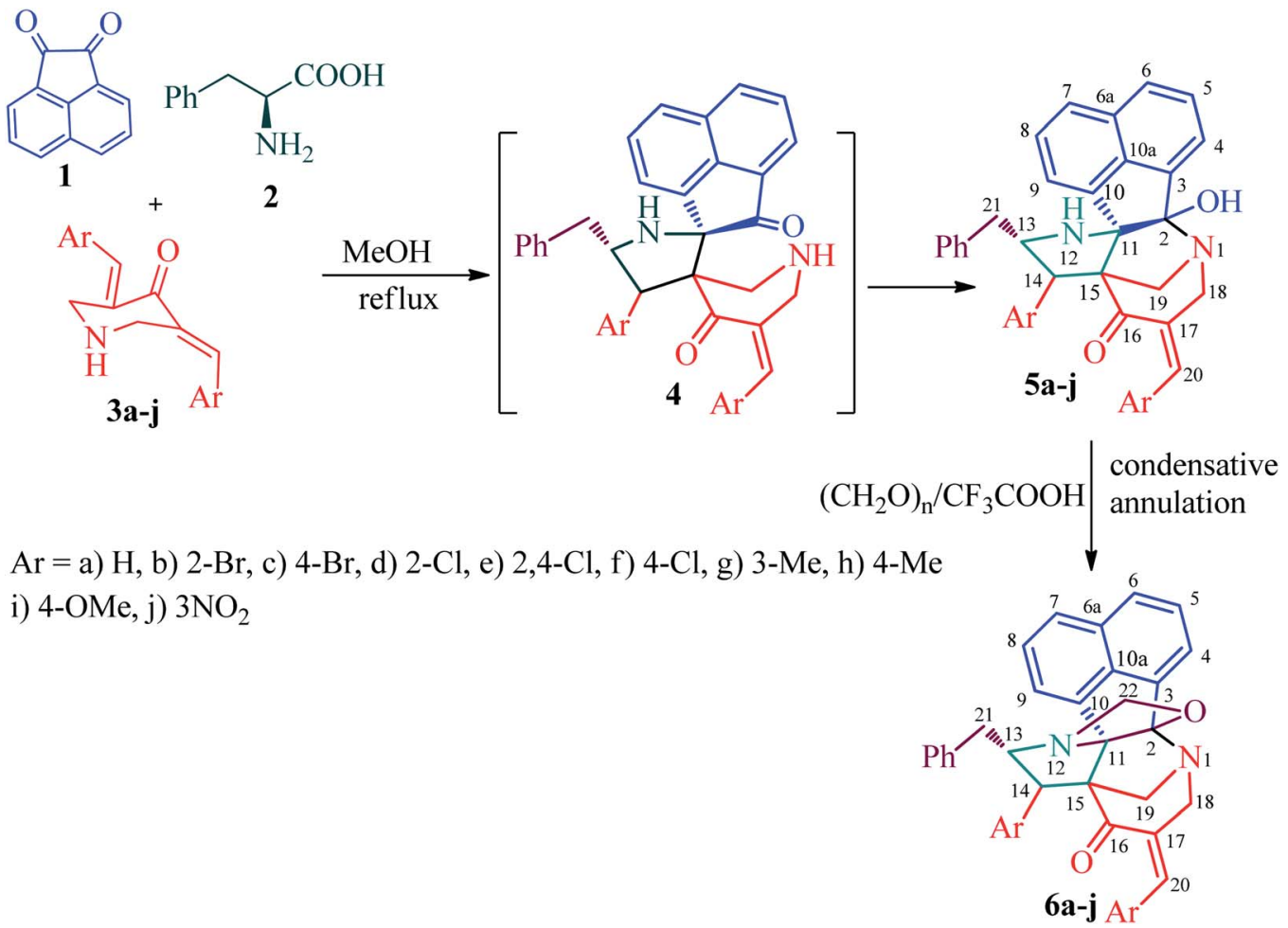

Scheme 1 Synthesis of diazahexa-/hepta cyclic cage compounds, $5 a-j$ and $6 a-j$.

like systems in good to excellent yields. The crude cage-like product 5 obtained was purified through column chromatography and its structure was confirmed by spectroscopic studies. With a series of diaza hexacyclic cage-like compound $\mathbf{5}$ in hand, we proceeded further to explore their reaction with paraformaldehyde in the presence of trifluoroacetic acid, which led to the formation of structurally interesting diazahepta cyclic cage-like compounds 6 comprising [1,2-c] oxazolidine, pyrrolidine, and piperidine structural units. In a typical reaction, diazahexacyclic cage-like compounds $5(1 \mathrm{mmol})$ were treated overnight with paraformaldehyde $(1 \mathrm{mmol})$ in the presence of a catalytic amount trifluoroacetic acid $(10 \mathrm{~mol} \%)$ in $\mathrm{CH}_{2} \mathrm{Cl}_{2}$ at room temperature which afforded 6 in excellent yields (8898\%). The structure of the synthesized compound was confirmed by ${ }^{1} \mathrm{H}$ and ${ }^{13} \mathrm{C}$ NMR spectroscopic studies and their stereochemistry has been unambiguously ascertained by single X-ray crystal analysis (Fig. 2) ${ }^{14}$ The plausible mechanism for the formation of diazahexa/hepta cyclic cage-like compounds $\mathbf{5}$ and 6 is described in Scheme 2.

\section{Biology}

Determining the antifungal activity of novel compounds. Preliminary screening of diazahexa/hepta cyclic cage system compounds synthesized in our laboratory was tested for its antifungal activity by mean inhibitory concentration (MIC) assay as described before. ${ }^{15}$ MIC for all the strains against indicated compounds were done in triplicates. Compounds 5 and $\mathbf{6}$ series were screened against the C. albicans ATCC 10231 strain. Results indicate that compounds $5 \mathbf{a}$ and $5 \mathbf{g}$ demonstrated antifungal activity with an MIC of $4 \mu \mathrm{g} \mathrm{mL} \mathrm{m}^{-1}$ (Table 1).
Next, we tested the antifungal activity of compounds $\mathbf{5 a}$ and $5 \mathrm{~g}$ against clinical strains of Candida spp. and Cryptococcus neoformans in order to determine if the compounds possess broad-spectrum activity against a variety of fungal species. After 24 hours of incubation, both $5 \mathbf{a}$ and $\mathbf{5 g}$ demonstrated potent antifungal activity against $C$. albicans, Candida parapsilosis, and Candida tropicalis with the MICs ranging from 0.5 to $4 \mu \mathrm{g} \mathrm{mL} \mathrm{m}^{-1}$ (Table 2). Further, $\mathbf{5 a}$ and $\mathbf{5 g}$ also inhibited the growth of these fungal strains even after 48 hours of incubation with the MICs ranging from 2 to $8 \mu \mathrm{g} \mathrm{mL} \mathrm{m}^{-1}$ (Table 2). Compounds $\mathbf{5 a}$ and $\mathbf{5 g}$ also showed excellent antifungal activity against $C$. neoformans and C. glabrata with the MICs ranging from 0.5 to $2 \mu \mathrm{g} \mathrm{mL} \mathrm{m}^{-1}$ after 48 hours of incubation (Table 2).

Fluconazole was used as a metric of comparison, due to its status as FDA-approved antifungal drug with widespread clinical use. Fluconazole inhibited the Candida strains with a wide range of MICs from 0.0625 to $16 \mu \mathrm{g} \mathrm{mL} \mathrm{m}^{-1}$ after 24 hours of incubation (Table 2). However, after 48 hours, the MICs of fluconazole for all strains were increased several fold with most strains inhibited at $32 \mu \mathrm{g} \mathrm{mL} \mathrm{m}^{-1}$ (Table 2). Surprisingly, unlike fluconazole, both compounds $\mathbf{5 a}$ and $\mathbf{5 g}$ showed potent inhibitory activity against most of the Candida strains, even after 48 hours of incubation without considerable increase in the MIC values. In addition, $\mathbf{5 a}$ and $\mathbf{5 g}$ also showed excellent antifungal activity against C. glabrata and C. neoformans after 48 hours of incubation compared to fluconazole (Table 2). Collectively, compounds $5 \mathbf{a}$ and $\mathbf{5 g}$ exhibit potent broad-spectrum antifungal activity compared to fluconazole against all the fungal strains tested in this study. 

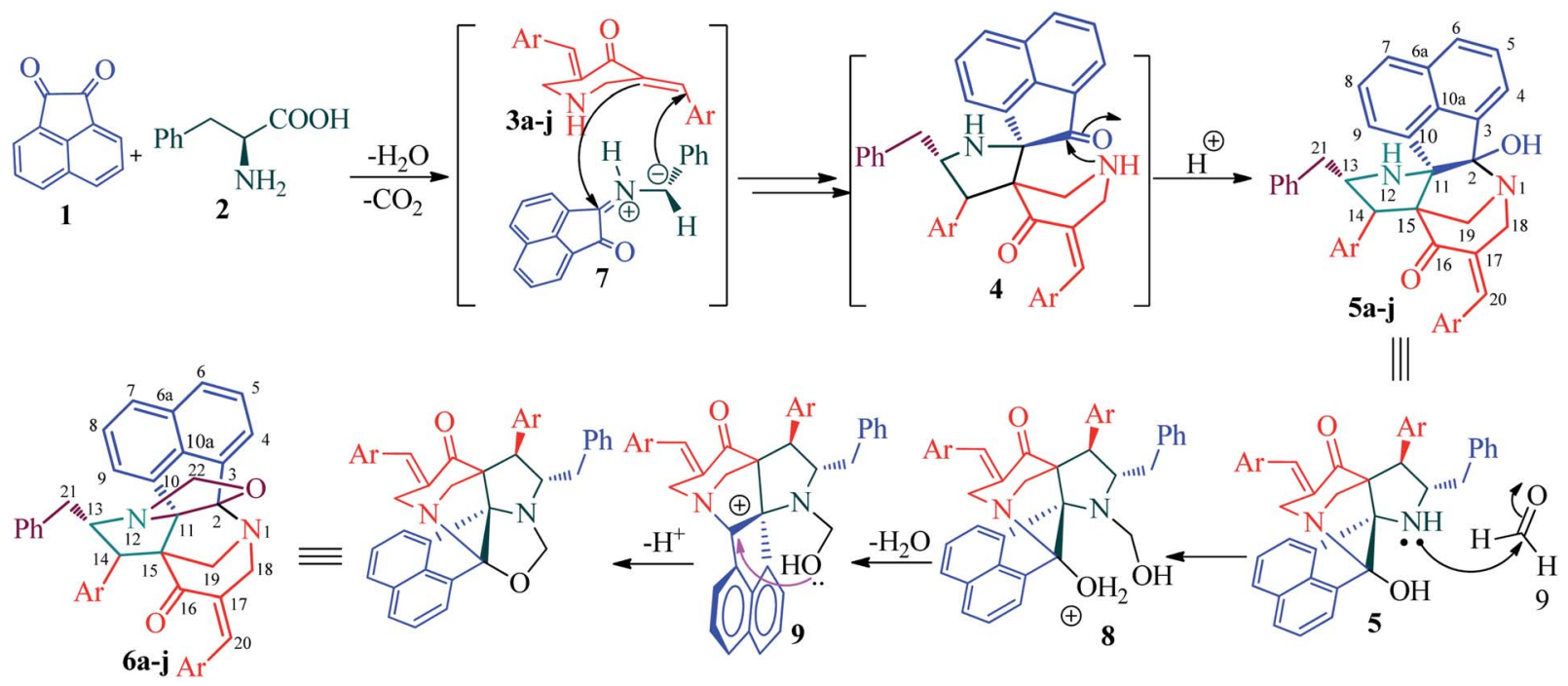

Scheme 2 Plausible mechanism for the formation of diazahexa-/heptacyclic cage system.

Compounds $5 \mathrm{a}$ and $5 \mathrm{~g}$ inhibit $\mathrm{C}$. albicans hyphae formation and attachment. The morphological switching ability of $C$. albicans from yeast to hyphae form is a key factor in the virulence of these pathogenic fungi. ${ }^{\mathbf{1 6 - 1 8}}$ Therefore, we tested the effect of compounds against $C$. albicans hyphae formation. $C$. albicans ATCC 10231 strain was grown in hyphae inducing medium containing fetal bovine serum (FBS) in the presence or absence of compounds and the hyphae formation and attachment was determined using the crystal violet assay as described before. ${ }^{\mathbf{1 9 , 2 0}}$ Results indicate that all compounds significantly inhibited the hyphae formation and attachment (Fig. 3). At a concentration of $128 \mu \mathrm{g} \mathrm{mL} \mathrm{m}^{-1}$, compounds $5 \mathbf{a}, \mathbf{5} \mathbf{g}$ and fluconazole significantly inhibited the hyphae formation and attachment by 90, 50 and $70 \%$ respectively (Fig. 3). At $256 \mu \mathrm{g}$ $\mathrm{mL}^{-1}$, compounds $\mathbf{5 a}$ and $\mathbf{5} \mathbf{g}$ showed almost complete inhibition (more than 90\%) of hyphae formation (Fig. 3). However, increasing the concentration of fluconazole $\left(256 \mu \mathrm{g} \mathrm{mL}^{-1}\right)$ did

Table 1 Screening compounds for antifungal activity against C. albicans ATCC 10231

\begin{tabular}{lll}
\hline Entry & Compounds & MIC $\left(\mu \mathrm{gL}^{-1}\right)$ \\
\hline 1 & $\mathbf{5 a}$ & 4 \\
2 & $\mathbf{5 b}$ & 128 \\
3 & $\mathbf{5 c}$ & 32 \\
4 & $\mathbf{5 d}$ & 128 \\
5 & $\mathbf{5 e}$ & 128 \\
6 & $\mathbf{5 f}$ & 128 \\
7 & $\mathbf{5 g}$ & 4 \\
8 & $\mathbf{5 h}$ & 256 \\
9 & $\mathbf{5 i}$ & 16 \\
10 & $\mathbf{5 j}$ & 16 \\
11 & $\mathbf{6 a}$ & 16 \\
12 & $\mathbf{6 c}$ & 64 \\
14 & $\mathbf{6 d}$ & 128 \\
15 & $\mathbf{6 g}$ & 64 \\
16 & $\mathbf{6 i}$ & 16
\end{tabular}

not improve the inhibitory activity (Fig. 3). Taken together, compounds $\mathbf{5 a}$ and $\mathbf{5 g}$ showed potent inhibitory effect on $C$. albicans hyphae formation and attachment in a concentration dependent manner, and showed excellent activity compared to fluconazole.

Compounds $5 \mathrm{a}$ and $5 \mathrm{~g}$ inhibit the metabolic activity of fungal cells in $\boldsymbol{C}$. albicans biofilm. Increased resistance by Candida spp. to antifungal therapies has been partially attributed to biofilm formation..$^{21,22}$ Fungal biofilms can also lead to recurrent infections. ${ }^{23,24}$ Therefore, we investigated the effect of compounds on $C$. albicans biofilm formation using an MTS reduction assay. Results indicate that $\mathbf{5 a}, \mathbf{5} \mathbf{g}$ and fluconazole significantly inhibited the metabolic activity of fungal cells in $C$. albicans biofilm (Fig. 4). Compounds 5a and $\mathbf{5 g}$ at the concentrations of 128 and $256 \mu \mathrm{g} \mathrm{mL} \mathrm{m}^{-1}$ inhibited the metabolic activity of fungal cells in the biofilm by 40 and $30 \%$ respectively (Fig. 4 ). Fluconazole also showed significant inhibition (30\%) at a concentration of $256 \mu \mathrm{g} \mathrm{mL} \mathrm{m}^{-1}$ (Fig. 4).

Cytotoxicity activity of compounds against mammalian cells. Fungi are eukaryotic pathogens, therefore developing therapeutic agents capable of inhibiting pathogenic fungal growth without mammalian host toxicity a significant challenge. Therefore, we determined to examine the cytotoxicity activity of compounds against mammalian cell lines using a MTS assay. Surprisingly, our results indicate that compounds $\mathbf{5 a}$ and $\mathbf{5 g}$ were not toxic to all the tested mammalian cell lines including human colon cancer cell line (HCT 116), mouse mammary gland cell line (4T1), mouse fibroblast cell line (CT26) and mouse lung cell line (LLC1) cells up to $256 \mu \mathrm{g} \mathrm{mL}{ }^{-1}$ (Fig. 5). Thus, it appears evident that compounds $5 \mathbf{a}$ and $\mathbf{5 g}$ possess antifungal activity without causing toxicity to mammalian cells.

Results from this study indicate that compounds 5a and $\mathbf{5 g}$ possess potent antifungal and antivirulence activities without causing mammalian host toxicity. In addition, 5a and $\mathbf{5 g}$ showed excellent activity compared to fluconazole. Further studies to determine the pharmacokinetic and physicochemical 
Table 2 MICs of compounds and fluconazole against clinical isolates of Candida spp. and C. neoformans ${ }^{a}$

\begin{tabular}{|c|c|c|c|c|c|c|c|}
\hline \multirow[b]{2}{*}{ Strain } & \multirow[b]{2}{*}{ Description } & \multicolumn{2}{|c|}{$\begin{array}{l}\text { MIC Fluconazole } \\
\left(\mu \mathrm{g} \mathrm{mL}^{-1}\right)\end{array}$} & \multicolumn{2}{|c|}{$\begin{array}{l}\text { MIC 5a }(\mu \mathrm{g} \\
\left.\mathrm{mL}^{-1}\right)\end{array}$} & \multicolumn{2}{|c|}{$\begin{array}{l}\text { MIC } 5 \mathbf{g}(\mu \mathrm{g} \\
\left.\mathrm{mL}^{-1}\right)\end{array}$} \\
\hline & & $24 \mathrm{~h}$ & $48 \mathrm{~h}$ & $24 \mathrm{~h}$ & $48 \mathrm{~h}$ & $24 \mathrm{~h}$ & $48 \mathrm{~h}$ \\
\hline C. albicans NR-29434 & $\begin{array}{l}\text { Bloodstream isolate from a patient with } \\
\text { candidemia from Winnipeg, Manitoba, } \\
\text { Canada in } 2000\end{array}$ & 0.125 & 32 & 4 & 8 & 2 & 4 \\
\hline C. albicans NR-29449 & $\begin{array}{l}\text { Vaginal isolate from a patient with } \\
\text { vaginitis from Ann Arbor, Michigan, USA } \\
\text { between } 1990 \text { and } 1992\end{array}$ & 0.5 & 32 & 4 & 8 & 4 & 8 \\
\hline C. albicans NR-29435 & $\begin{array}{l}\text { Bloodstream isolate from a patient with } \\
\text { candidemia from Iowa City, Iowa, USA in } \\
2000\end{array}$ & 0.5 & 0.5 & 2 & 4 & 2 & 4 \\
\hline C. albicans NR-29448 & $\begin{array}{l}\text { Clinical isolate from a person with } \\
\text { candidemia from Arizona, USA }\end{array}$ & 1 & 32 & 2 & 8 & 2 & 4 \\
\hline C. albicans NR-29437 & $\begin{array}{l}\text { Bloodstream isolate from a patient with } \\
\text { candidemia from Brussels, Belgium in } \\
2000\end{array}$ & 0.25 & 32 & 4 & 8 & 2 & 4 \\
\hline C. albicans NR-29446 & $\begin{array}{l}\text { Bloodstream isolate from a patient with } \\
\text { candidemia from Utah, USA }\end{array}$ & 16 & 32 & 1 & 4 & 0.5 & 4 \\
\hline C. albicans NR5-29453 & $\begin{array}{l}\text { Clinical isolate from a patient with } \\
\text { thrush and HIV from Pretoria, South } \\
\text { Africa }\end{array}$ & 0.0625 & 0.0625 & 4 & 4 & 2 & 4 \\
\hline C. albicans NR-29438 & $\begin{array}{l}\text { Bloodstream isolate from a patient with } \\
\text { candidemia from Tel-Hashomer, Israel, } \\
\text { in } 2000\end{array}$ & 0.0625 & 0.25 & 4 & 8 & 2 & 4 \\
\hline C. albicans NR-29367 & Clinical isolate from China & 0.0625 & 0.0625 & 4 & 4 & 2 & 4 \\
\hline C. albicans NR-29439 & $\begin{array}{l}\text { Bloodstream isolate from a patient with } \\
\text { candidemia from Omaha, Nebraska, } \\
\text { USA, in } 2000\end{array}$ & 0.5 & 32 & 2 & 8 & 2 & 4 \\
\hline C. albicans NR-29440 & $\begin{array}{l}\text { Bloodstream isolate from a patient with } \\
\text { candidemia from Lille, France, in } 2000\end{array}$ & 0.25 & 0.5 & 4 & 8 & 2 & 4 \\
\hline C. albicans NR-29441 & $\begin{array}{l}\text { Bloodstream isolate from a patient with } \\
\text { candidemia from Iowa City, Iowa, USA, in } \\
2000\end{array}$ & 0.25 & 16 & 2 & 8 & 1 & 4 \\
\hline C. albicans NR-29442 & $\begin{array}{l}\text { Bloodstream isolate from a patient with } \\
\text { candidemia from Ottawa, Ontario, } \\
\text { Canada, in } 2000\end{array}$ & 0.25 & 32 & 4 & 8 & 2 & 4 \\
\hline C. albicans NR-29444 & $\begin{array}{l}\text { Oral isolate from a patient with vaginitis } \\
\text { collected in Ann Arbor, Michigan, USA } \\
\text { between } 1990 \text { and 1992. }\end{array}$ & 1 & 16 & 2 & 4 & 2 & 4 \\
\hline C. parapsilosis ATCC 22019 & $\begin{array}{l}\text { Clinical isolate from a patient with celiac } \\
\text { disease from Puerto Rico }\end{array}$ & 1 & 4 & 0.5 & 2 & 0.5 & 2 \\
\hline C. tropicalis ATCC 13803 & FDA provided isolate & 8 & 32 & 4 & 8 & 2 & 4 \\
\hline C. glabrata ATCC 90030 & $\begin{array}{l}\text { Bloodstream isolate from a patient from } \\
\text { Iowa }\end{array}$ & n.d. & 4 & n.d. & 0.5 & n.d. & 0.5 \\
\hline C. albicans ATCC 10231 & $\begin{array}{l}\text { Clinical isolate from a patient with } \\
\text { bronchomycosis }\end{array}$ & 2 & 4 & 2 & 4 & 1 & 4 \\
\hline C. neoformans NR-41291 & $\begin{array}{l}\text { Cerebrospinal fluid isolate from a patient } \\
\text { from China in July } 2011\end{array}$ & n.d. & 32 & n.d. & 2 & n.d. & 2 \\
\hline C. neoformans NR-41292 & $\begin{array}{l}\text { Cerebrospinal fluid isolate from a patient } \\
\text { from China in February } 2012\end{array}$ & n.d. & 32 & n.d. & 1 & n.d. & 1 \\
\hline C. neoformans NR-41296 & $\begin{array}{l}\text { Cerebrospinal fluid isolate from a patient } \\
\text { from China in February } 2012\end{array}$ & n.d. & 4 & n.d. & 1 & n.d. & 1 \\
\hline C. neoformans NR-41295 & $\begin{array}{l}\text { Cerebrospinal fluid isolate from a patient } \\
\text { from China in February } 2012\end{array}$ & n.d. & 32 & n.d. & 1 & n.d. & 1 \\
\hline C. neoformans NR-41294 & $\begin{array}{l}\text { Cerebrospinal fluid isolate from a patient } \\
\text { from China in June } 2011\end{array}$ & n.d. & 4 & n.d. & 0.5 & n.d. & 0.5 \\
\hline C. neoformans NR-41297 & $\begin{array}{l}\text { Cerebrospinal fluid isolate from a patient } \\
\text { from China in February } 2012\end{array}$ & n.d. & 8 & n.d. & 1 & n.d. & 1 \\
\hline C. neoformans NR-41298 & $\begin{array}{l}\text { Cerebrospinal fluid isolate from a patient } \\
\text { from China in February } 2012\end{array}$ & n.d. & 16 & n.d. & 2 & n.d. & 2 \\
\hline C. neoformans NR-41299 & $\begin{array}{l}\text { Cerebrospinal fluid isolate from a patient } \\
\text { from China in August } 2009\end{array}$ & n.d. & 8 & n.d. & 1 & n.d. & 1 \\
\hline
\end{tabular}

${ }^{a}$ Not detected (n.d.). 


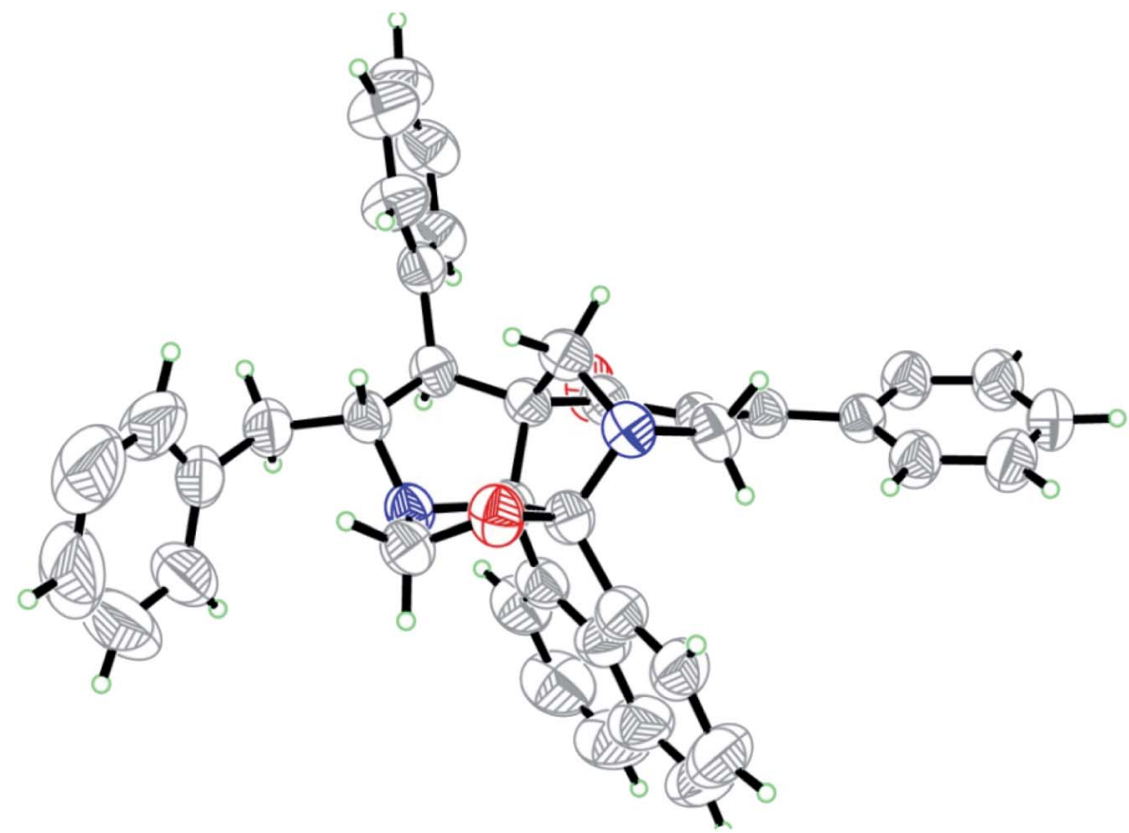

Fig. 2 ORTEP diagram of compound 6 a.

profile of these compounds is essential to move these compounds to the next stage of the drug development pipeline. The structure of $5 \mathbf{a}$ and $\mathbf{5 g}$ contain the nitrogen (N1) atom in the diazahexa cage-like compounds, a characteristic shared by the benzylamine and allylamine antifungals. These antifungals act as inhibitors of squalene epoxidase, a key enzyme in the synthesis of sterols by fungi. The nitrogen (N12) atom in the pyrrolidine ring shares similar bonding to that of

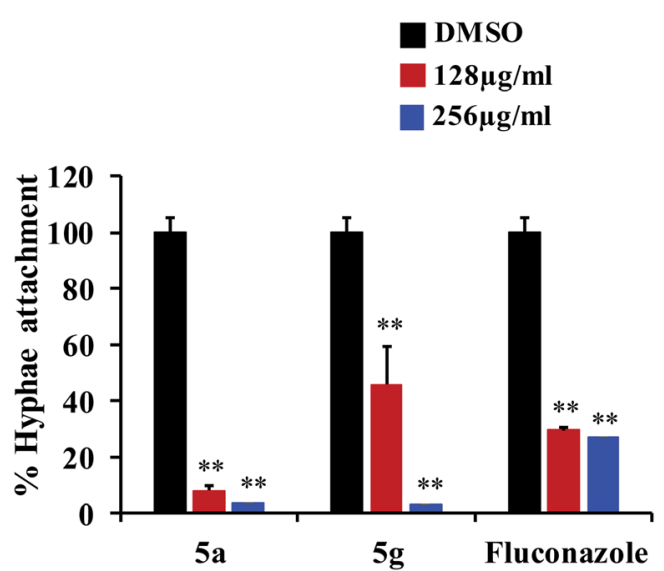

Fig. 3 Activity of compounds $5 \mathrm{a}$ and $5 \mathrm{~g}$ against $C$. albicans hyphae formation and attachment. C. albicans ATCC 10231 was incubated with the indicated compounds or DMSO for 12 hours in the hyphae inducing conditions and the adherent hyphae was stained using crystal violet. Absorbance measured at $490 \mathrm{~nm}$ and the percent hyphae formation and attachment in treatment groups was determined relative to DMSO treated control groups. Experiments were repeated atleast three times in triplicates and the data represented as means \pm SEM of all replicates. The statistical significance with $P$ values $(* \leq 0.05$, $* * \leq 0.01$ ) were considered significant as per $t$-test. echinocandins, which act as beta-1, 3-D-glucan synthase inhibitors. The carbonyl unit of piperidone at position sixteen shares similarities to that of the flavonoids, which have become a new area of study for their antifungal activity. Therefore, we speculate that these novel compounds may target pathways specific to fungi including fungal 3b-glucan synthase and ergosterol biosynthesis. ${ }^{25}$ However, future studies will be needed to understand the antifungal mechanism of these compounds. In addition, further structure modifications to enhance the activities of $5 \mathbf{a}$ and $5 \mathbf{g}$ should be also a promising avenue. Taken

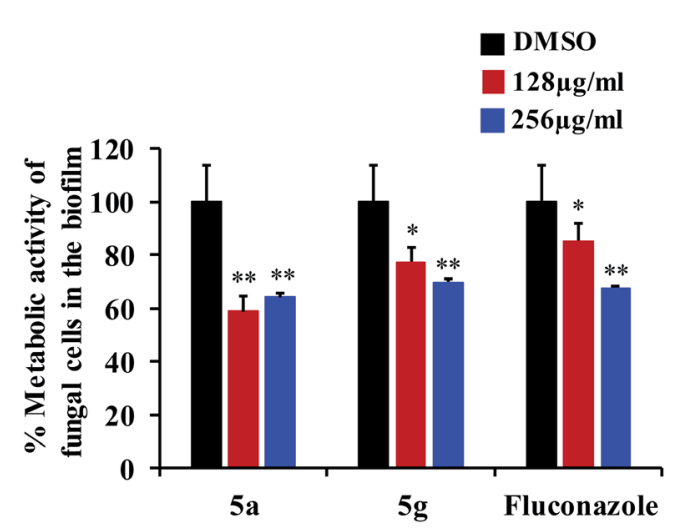

Fig. 4 Effect of compounds $5 \mathrm{a}$ and $5 \mathrm{~g}$ on the metabolic activity of $C$. albicans cells in fungal biofilm. C. albicans ATCC 10231 was incubated under biofilm inducing conditions in the presence or absence of indicated compounds or DMSO and after 48 hours of incubation the metabolic activity of fungal cells in the biofilm was determined using the MTS assay. Percent metabolic activity in the treatment groups was calculated in relative to the DMSO control group. Experiments were repeated atleast three times in triplicates and the data represented as means \pm SEM of all replicates. The statistical significance with $P$ values $(* \leq 0.05, * * \leq 0.01)$ were considered significant as per $t$-test. 
A)

B)
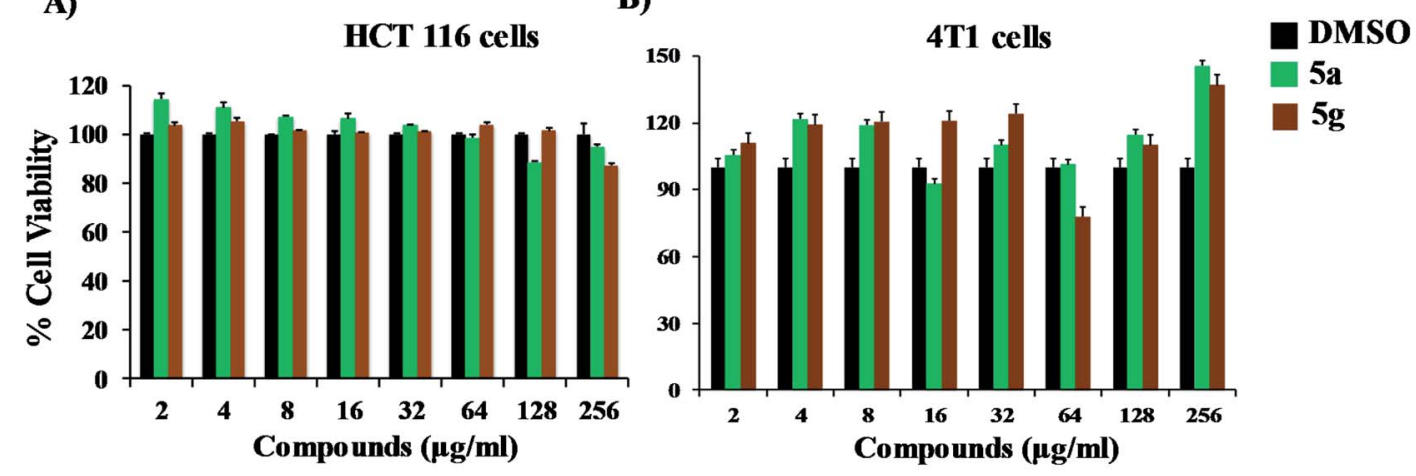

C)

CT26 cells

D)
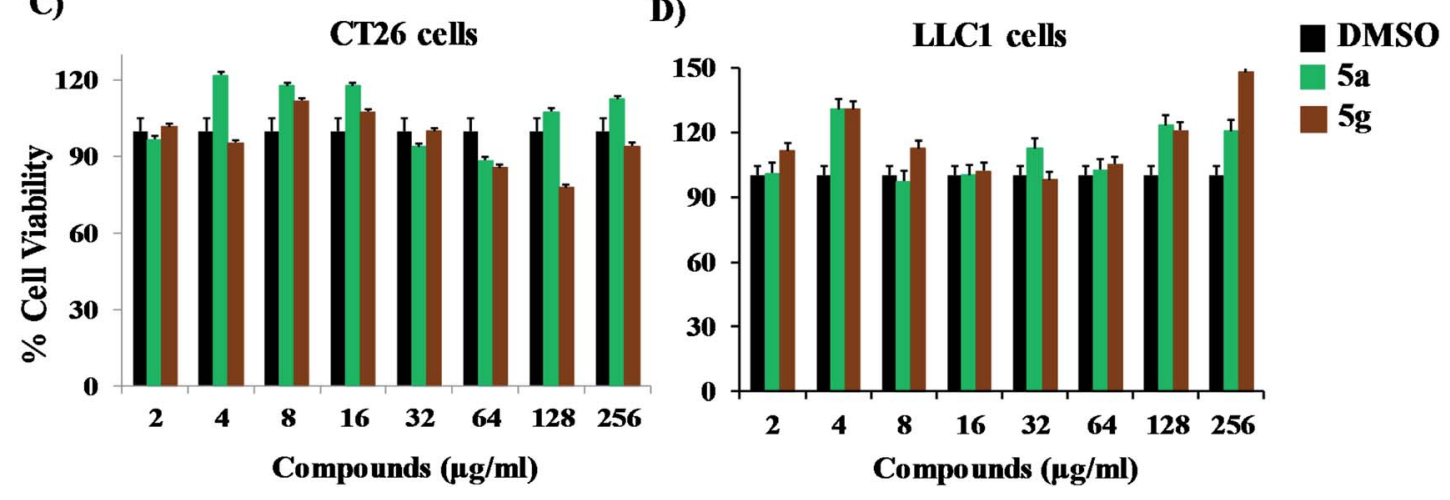

Fig. 5 Cytotoxicity assay in mammalian cells. Mammalian cell lines including human colon cancer cell line (HCT 116), mouse mammary gland cell line (4T1), mouse fibroblast cell line (CT26) and mouse lung cell line (LLC1) cells (A, B, C and D respectively) were incubated with the indicated concentrations of compounds and, after 24 hours of incubation, the cell viability was measured using the MTS assay. Percent cell viability was calculated relative to the DMSO treated control groups. Experiments were repeated atleast three times in triplicates and the data represented as means \pm SEM of all replicates. The statistical significance with $P$ values $(* \leq 0.05, * * \leq 0.01)$ were considered significant as per $t$-test.

together, compounds $\mathbf{5 a}$ and $\mathbf{5} \mathbf{g}$ have strong potential to develop as novel antifungal drugs.

\section{Materials and methods}

\section{Chemistry}

General procedure for the synthesis of hexacyclic compounds $\mathbf{5 a - j}$. An equimolar mixture of 3,5-bisarylmethylidene pyridinone $(1 \mathrm{mmol})$, acenaphthenequinone $(1$ mmol) and L-phenylalanine $(1 \mathrm{mmol})$ was dissolved in $\mathrm{MeOH}$ $(15 \mathrm{~mL})$ and refluxed for $2 \mathrm{~h}$. After completion of the reaction evident by TLC, diazahexacyclic cage compound were afforded in pure form through column chromatography using EtOAc : hexane $(7: 3 \mathrm{v} / \mathrm{v})$ as eluent.

General procedure for the synthesis of heptacyclic compounds 6a-g. An equimolar mixture of hexacyclic compound $5(1 \mathrm{mmol})$ and paraformaldehyde $(1 \mathrm{mmol})$ was dissolved in $\mathrm{CH}_{2} \mathrm{Cl}_{2}(5 \mathrm{~mL})$ and then added a catalytic amount of trifluoroacetic acid $(10 \mathrm{~mol} \%)$. The mixture was stirred overnight at room temperature. After completion of the reaction as evident from TLC, diazahexacyclic cage compound were afforded in pure form through column chromatography using EtOAc : hexane $(1: 4 \mathrm{v} / \mathrm{v})$ as the eluent and recrystallized from EtOAc.

\section{Biology}

MIC assay. Mean inhibitory concentration (MIC) was performed as per CLSI standards as described before..$^{15,26,27}$ Briefly, fungal strains were suspended in phosphate buffered saline to match a 0.5 McFarland standard (about $10^{6} \mathrm{CFU} \mathrm{mL}{ }^{-1}$ approximately), and then diluted in RPMI 1640 to create a $10^{2}$ to $10^{3} \mathrm{CFU} \mathrm{mL} \mathrm{m}^{-1}$ solution. $100 \mu \mathrm{L}$ of this inoculated solution was placed in the wells of a 96-well untreated plate and incubated for 24 and 48 hours in the presence or absence of indicated compounds listed in Table 2 or DMSO. MIC was recorded after 24 and 48 hours of incubation.

Hyphae assay. The effect of compounds on Candida hyphae formation and attachment was performed as described previously ${ }^{19,20}$ Briefly, C. albicans ATCC 10231 strain was incubated for 16 hours at $37{ }^{\circ} \mathrm{C}$ in hyphae inducing media $(30 \%$ fetal bovine serum, 70\% RPMI 1640) in a 96-well untreated plate in the presence or absence of indicated compounds or DMSO control. After incubation, wells were washed and stained with $0.02 \%$ crystal violet and the absorbance measured at $490 \mathrm{~nm}$ using a spectrophotometer. Percent hyphae attachment was calculated relative to the vehicle control groups.

Biofilm assay. The effect of compounds on C. albicans biofilm formation was determined using C. albicans ATCC 10231 as 
descried elsewhere. ${ }^{\mathbf{1 9 , 2 0 , 2 7 , 2 8}}$ C. albicans was resuspended in RPMI 1640 medium at a concentration of $3 \times 10^{6}$ cells per mL, then $100 \mu \mathrm{L}$ of inoculum were transferred to the wells of a 96well treated plate and incubated in the presence or absence of indicated compounds. The plate was incubated for 48 hours at $37{ }^{\circ} \mathrm{C}$ and the metabolic activity of fungal cells in C. albicans biofilm was determined using MTS assay. Absorbance was measured at $490 \mathrm{~nm}$ using a spectrophotometer and the percent metabolic activity was determined in relative to the DMSO treated control groups.

Cytotoxicity assay. The toxic effect of compounds against mammalian cells was investigated using human colon cancer cell line (HCT 116), mouse mammary gland cell line (4T1), mouse fibroblast cell line (CT26) and mouse lung cell line (LLC1) cells as described previously. ${ }^{15,27}$ HCT116 and LLC1 cells were cultured in FBS-supplemented DMEM media, 4T1 and CT26 cells were cultured in FBS-supplemented RPMI media containing penicillin-streptomycin at $37^{\circ} \mathrm{C}$ for 24 hours in the presence or absence of indicated concentrations of compounds. Cell viability was measured by MTS assay and the percent viable cells in the treatment group was determined relative to the DMSO control groups.

Statistical analysis. Statistical significance was assessed using student's $t$-test and $P$ values $(* \leq 0.05, * * \leq 0.01)$ were considered as significant.

\section{Conflicts of interest}

The authors declare that there are no conflicts of interest.

\section{Acknowledgements}

The authors acknowledge the Deanship of Scientific Research at King Saud University for the funding this work through the Research Grant RGP-026.

\section{References}

1 T. P. McCarty and P. G. Pappas, Invasive Candidiasis, Infect. Dis. Clin. N. Am., 2016, 30(1), 103-124.

2 M. Bassetti, D. R. Giacobbe, A. Vena, C. Trucchi, F. Ansaldi, M. Antonelli, et al., Incidence and outcome of invasive candidiasis in intensive care units (ICUs) in Europe: results of the EUCANDICU project, Crit. Care, 2019, 23(1), 219.

3 E. Ghrenassia, D. Mokart, J. Mayaux, A. Demoule, I. Rezine, L. Kerhuel, et al., Candidemia in critically ill immunocompromised patients: report of a retrospective multicenter cohort study, Ann. Intensive Care, 2019, 9(1), 62.

4 Z. Xiao, Q. Wang, F. Zhu and Y. An, Epidemiology, species distribution, antifungal susceptibility and mortality risk factors of candidemia among critically ill patients: a retrospective study from 2011 to 2017 in a teaching hospital in China, Antimicrob. Resist. Infect. Contr., 2019, 8, 89.

5 J. McKenney, S. Bauman, B. Neary, R. Detels, A. French, J. Margolick, et al., Prevalence, correlates, and outcomes of cryptococcal antigen positivity among patients with AIDS,
United States, 1986-2012, Clin. Infect. Dis., 2015, 60(6), 959965.

6 S. G. Whaley, E. L. Berkow, J. M. Rybak, A. T. Nishimoto, K. S. Barker and P. D. Rogers, Azole Antifungal Resistance in, Front. Microbiol., 2016, 7, 2173.

7 F. Bongomin, R. O. Oladele, S. Gago, C. B. Moore and M. D. Richardson, A systematic review of fluconazole resistance in clinical isolates of Cryptococcus species, Mycoses, 2018, 61(5), 290-297.

8 J. R. Perfect, W. E. Dismukes, F. Dromer, D. L. Goldman, J. R. Graybill, R. J. Hamill, et al., Clinical practice guidelines for the management of cryptococcal disease: 2010 update by the infectious diseases society of america, Clin. Infect. Dis., 2010, 50(3), 291-322.

9 D. W. Denning, Echinocandins: a new class of antifungal, $J$. Antimicrob. Chemother., 2002, 49(6), 889-891.

10 T. Roemer and D. J. Krysan, Antifungal drug development: challenges, unmet clinical needs, and new approaches, Cold Spring Harbor Perspect. Med., 2014, 4(5), 1-14.

11 B. de Pauw, Is there a need for new antifungal agents?, Clin. Microbiol. Infect., 2000, 6(2), 23-28.

12 D. J. Krysan, The unmet clinical need of novel antifungal drugs, Virulence, 2017, 8(2), 135-137.

13 N. Arumagam, A. I. Almansour, R. Suresh Kumar, S. Perumal, H. A. Ghabbour and H.-K. Fun, A 1,3-dipolar cycloaddition-annulation protocol for the expedient regio-, stereo- and product-selective construction of novel hybrid heterocycles comprising seven rings and seven contiguous stereocentres, Tetrahedron Lett., 2013, 2515-2519.

14 Crystallographic data (excluding structure factors) for heptacyclic compound $\mathbf{6 a}$ in this letter have been deposited with the Cambridge Crystallographic Data Centre as supplementary publication number CCDC 917844.

15 S. Thangamani, M. Maland, H. Mohammad, P. E. Pascuzzi, L. Avramova, C. M. Koehler, et al., Repurposing Approach Identifies Auranofin with Broad Spectrum Antifungal Activity That Targets Mia40-Erv1 Pathway, Front. Cell. Infect. Microbiol., 2017, 7, 4.

16 C. A. Kumamoto and M. D. Vinces, Contributions of hyphae and hypha-co-regulated genes to Candida albicans virulence, Cell. Microbiol., 2005, 7(11), 1546-1554.

17 R. A. Calderone and W. A. Fonzi, Virulence factors of Candida albicans, Trends Microbiol., 2001, 9(7), 327-335.

18 R. Pukkila-Worley, A. Y. Peleg, E. Tampakakis and E. Mylonakis, Candida albicans hyphal formation and virulence assessed using a Caenorhabditis elegans infection model, Eukaryotic Cell, 2009, 8(11), 1750-1758.

19 J. Guinan, S. Wang, T. R. Hazbun, H. Yadav and S. Thangamani, Antibiotic-induced decreases in the levels of microbial-derived short-chain fatty acids correlate with increased gastrointestinal colonization of Candida albicans, Sci. Rep., 2019, 9(1), 8872.

20 J. Guinan, P. Villa and S. Thangamani, Secondary bile acids inhibit Candida albicans growth and morphogenesis, Pathog. Dis., 2018, 76(3), 1-8. 
21 L. Mathé and P. Van Dijck, Recent insights into Candida albicans biofilm resistance mechanisms, Curr. Genet., 2013, 59(4), 251-264.

22 G. Ramage, S. Bachmann, T. F. Patterson, B. L. Wickes and J. L. Lopez-Ribot, Investigation of multidrug efflux pumps in relation to fluconazole resistance in Candida albicans biofilms, J. Antimicrob. Chemother., 2002, 49(6), 973-980.

23 C. A. Muzny and J. R. Schwebke, Biofilms: An Underappreciated Mechanism of Treatment Failure and Recurrence in Vaginal Infections, Clin. Infect. Dis., 2015, 61(4), 601-606.

24 J. V. Desai, A. P. Mitchell and D. R. Andes, Fungal biofilms, drug resistance, and recurrent infection, Cold Spring Harbor Perspect. Med., 2014, 4(10), 1-18.

25 M. A. Ghannoum and L. B. Rice, Antifungal agents: mode of action, mechanisms of resistance, and correlation of these mechanisms with bacterial resistance, Clin. Microbiol. Rev., 1999, 12(4), 501-517.
26 S. Thangamani, H. E. Eldesouky, H. Mohammad, P. E. Pascuzzi, L. Avramova, T. R. Hazbun, et al., Ebselen exerts antifungal activity by regulating glutathione (GSH) and reactive oxygen species (ROS) production in fungal cells, Biochim. Biophys. Acta, Gen. Subj., 2017, 1861(1), 3002-3010.

27 P. Villa, N. Arumugam, A. I. Almansour, R. Suresh Kumar, S. M. Mahalingam, K. Maruoka, et al., Benzimidazole tethered pyrrolo[3,4- $b]$ quinoline with broad-spectrum activity against fungal pathogens, Bioorg. Med. Chem. Lett., 2019, 29(5), 729-733.

28 C. G. Pierce, P. Uppuluri, A. R. Tristan, F. L. Wormley, E. Mowat, G. Ramage, et al., A simple and reproducible 96well plate-based method for the formation of fungal biofilms and its application to antifungal susceptibility testing, Nat. Protoc., 2008, 3(9), 1494-1500. 